\title{
Forest flora and vegetation of the European early Palaeogene - a review
}

\author{
ZLATKO KVAČEK
}

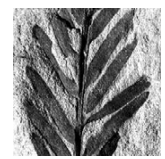

\begin{abstract}
An attempt is made to follow the extent of forest types during the Palaeocene and Eocene in time and space over Europe. Problems that hinder producing more detailed maps of potential Eocene vegetation are the different palaeogeographic configuration of land and sea and changing relief due to orogeny, the variation in global climate, atmospheric circulation and the world ocean. The early Palaeogene palaeofloristic sites in Europe are widely spaced and the data so far obtained are of varying quality from one site to another. The differences between zonal, intrazonal (azonal) and extrazonal formations and impact of precipitation must be considered. Objective definitions of units based on diversity percentages of components are still to be elaborated. The macropalaeobotanical data thus far available allow us to distinguish intuitively three zonal vegetation types: 1) Broad-leaved evergreen/semi-evergreen quasi-paratropical forest with a high diversity of woody angiosperms related to tropical families, ferns and a low diversity of conifers (mostly Doliostrobus), 2) Broad-leaved nothophyllous evergreen forest with evergreen Fagaceae, Lauraceae, Altingiaceae, Myrtaceae and some conifers (Pinus, Doliostrobus, Cephalotaxus) and 3) Polar deciduous to mixed mesophytic forest with well diversified angiosperms predominantly deciduous and moderate representation of Ginkgo, conifers and ferns. Intrazonal (azonal) formations include riparian gallery forests, coal-forming swamp forests, and poorly developed mangroves with marginal freshwater wetland/aquatic vegetation. The Eocene extrazonal vegetation is less distinct in Europe, consisting probably of pine forests in high mountains and lowland sclerophyllous scrub on specific substrates. $\bullet$ Key words: Palaeocene, Eocene, Europe, flora, vegetation, phytogeography.
\end{abstract}

KVAČEK, Z. 2010. Forest flora and vegetation of the European early Palaeogene - a review. Bulletin of Geosciences 85(1), 63-76 (1 figure, 1 table). Czech Geological Survey, Prague. ISSN 1214-1119. Manuscript received May 6, 2009; accepted in revised form October 5, 2009; published online January 8, 2010; issued March 22, 2010.

Zlatko Kvaček, Charles University, Faculty of Science, Albertov 6, 12843 Prague 2, Czech Republic; kvacek@natur.cuni.cz.

This account is an extended contribution to the symposium on Palaeogene floras and global change events held at the $7^{\text {th }}$ European Palaeobotany and Palynology Conference in Prague 2006. It revises and expands on the general overview of Eurasian floras by Collinson \& Hooker (2003) by providing significant detailed and up-to-date information and preliminary vegetation reconstructions for the European Palaeogene. The paper is based entirely on the macrofossil record and does not consider palynological data. It is rather incomplete because early Palaeogene paleobotanical sites in Europe are rather widely spaced and their floras not always properly worked out. The review of the floras follows the updated system of Floral Assemblages (= "Florenkomplexe") published by Mai (1995) with additional references on recent advances in systematic studies, notably of woody plant elements. Reconstructions of ancient forest vegetation are based on approaches considering both foliage physiognomy and the floristic composition.

To assess more objectively the differences between various types of vegetation, a new statistical approach has been suggested for the Neogene plant assemblages. This approach evaluates proportions of different components, in particular broad-leaved mesophytic dicots in connection with their leaf physiognomy (Kovar-Eder et al. 2008). The present attempt is a start for future potential application of a similar approach for the Eocene. It is certainly very incomplete because full analyses of plant assemblages at various sites are mostly hindered due to preservation and the state of taxonomic revisions. Also the role and palaeoecological properties of many early Palaeogene plant elements are uncertain, because they are much more distant from their modern analogues than in the Neogene.

Opinions on climatic proxies during the Palaeocene-Eocene differ according to various authors as well as do views of plant composition at different sites (Golovneva 2000, Uhl et al. 2007). Therefore, many of vegetation reconstructions suggested below are oversimplified in this assessment and must be considered only tentative. 


\section{RESULTS}

Floristic analysis and the "Florenkomplex" concept

The European Palaeocene-Eocene flora was reviewed and subdivided according to the bio-provinces by Mai (1995). He suggested a new grouping according to the concept of a "Florenkomplex", or "Florenbild", or "Floral Assemblage" introduced by Mai \& Walther (1978, p. 168), which is based on floristic properties as well as the stratigraphic position of related floras independent of the environment/vegetation type (hence the term "Komplex"). The present overview follows in general the same concept detailed in Mai \& Walther (2000) but stresses the necessity to replace the system of the "Florenkomplex" groups by a more appropriate system in the future. The term "Florenkomplex" uses a pre-occupied term "complex" that is also employed in lithostratigraphy. (Therefore it is replaced by "unit" in the following text). However, revision of the "Florenkomplex" would require a re-definition and re-naming of Mai and Walther's units. The extent of these units in time and space would need to be updated and more stress should be laid upon more critical re-appraisal of plant elements. Such a revision is beyond the scope of the present paper. The present "state-of-the-art" is summarized in Table 1.

\section{Atlantic Boreal Province}

European Arctic. - Mai's system of "Florenkomplexe" (Mai 1995, pp. 340-342) starts with the northern part of the Atlantic-Boreal bioprovince called also the Greenland Region sensu Seward (1931) or the Thule Province p.p. sensu Budantsev (1983). This region also includes the BritoArctic Igneous Province sensu Boulter \& Manum (1989) and extends as far southwards as to northern France in the Palaeocene. During the period from the early Palaeocene to the Eocene/Oligocene transition, three units have been recognized in the European Arctic.

The oldest is called "Atanikerdluk", and is Danian in age. It is represented first of all by well known floras occurring at several sites in western Greenland (Heer 1868, 1869, 1874, 1883; Koch 1963). The assemblage has been called "Macclintockia-Metasequoia-Cercidiphyllum" (Koch 1963), the latter element representing obviously the extinct forms also known as the Trochodendroides-Nyssidium plant. Additional noteworthy dicots have been recognized as extinct "Lauraceaephyllum stenolobatus" with affinities to Sassafras (Koch 1963), the Nordenskioldia-Ziziphoides plant, Fagopsiphyllum groenlandicum (Manchester 1999), Ushia olafsenii (Boulter \& Kvaček 1989) probably synonymous with Rarytkinia quercifolia (Golovneva 2000), Platanus bella (Kvaček et al. 2001), and Sloanea ungeri
(Manchester 1999, Manchester \& Kvaček 2009). Among gymnosperms Ginkgo and various ancient Cupressaceae (Metasequoia, Mesocyparis) and Pinaceae (Pseudolarix) occur. The other sites of approximately the same age are known also in the Spitsbergen Firkanten Formation (Budantsev 1983, Kvaček et al. 1994, Golovneva 2000), and share some endemic elements (e.g., "Quercus" juglandina), but differ by the presence of Torrelia (Ginkgoaceae) and the lack of Macclintockia dentata and Platanus bella.

The next unit is called "Antrim" and is dated to the Late Palaeocene. A most representative flora belonging here is that of Isle of Mull (Boulter \& Kvaček 1989). It includes the noteworthy Onoclea among ferns, new gymnosperms, namely Amentotaxus, Cephalotaxus(?), Elatocladus, and also new angiosperms like Platanites hebridicus, Camptodromites major, Davidoidea and Calycites ardtunensis (Crane 1988, Crane et al. 1988, Boulter \& Kvaček 1989), but differs from the Atanikerdluk unit in scarcity of Metasequoia. A few florulas in Ballypallady and Glenarm, Ireland, have several typical conifers, like Glyptostrobus dunoyeri, Cupressoconus machenryii and Pinus plutonis (Boulter \& Kvaček 1989). Some others in the Isle of Skye (Poulter et al. 2009), Faeroes (Rasmussen \& Koch 1963) and elsewhere (Mai 1995) are again rich in Metasequoia.

The Eocene floral unit called "Bröggerhalvøya" (Mai 1995 ) is mainly represented in Spitsbergen (Heer 1870, 1876; Storvola taphoflora sensu Budantsev 1983; Golovneva 2000) and includes the Aspelintoppen and Renardodden formations (Schloemer-Jäger 1958; Kvaček \& Manum 1993, 1997; Kvaček et al. 1994; Uhl et al. 2007). Floristic differences from the two older units are not very pronounced (Mai 1995), particularly expressed mainly among angiosperms, where new elements appeared: the Craigia bronnii/Dombeyopsis plant (Kvaček et al. 2005), Aesculus longipedunculus, Ulmus (or Ulmites), Platimelis and Haemanthophyllum (Golovneva 2000; Uhl et al. 2007). The Renardodden Fm. yielded a new conifer Taiwania schaeferi (Schloemer-Jäger 1958). The fern Coniopteris blomstrandii (Kvaček \& Manum 1993) is also a characteristic element. A similar but poorer late Danian flora is known in north Greenland as the Thyra Ø flora (Boyd 1990). The Eocene Ifsorisok flora of West Greenland belongs also to the unit Bröggerhalvøya, where Aesculus and Ulmus are lacking (Golovneva 2000) but this flora requires taxonomic revision.

Western and Central Europe. - Most west-central European sites of early Palaeogene floras have been grouped (Mai 1995, Mai \& Walther 2000) into three Palaeocene units, called Eisleben-Roda, Gelinden and Menat and mostly six Eocene units stretching into late Palaeocene and earliest Oligocene: Reading-Vervins, Belleu-Sheppey, Messel-Selsey, Scheiplitz, Hordle-Zeitz and BembridgeSpechbach. The oldest unit includes the Eisleben Basin in 
Table 1. Updated overview of Palaeocene and Eocene Floral Assemblages ("Florenkomplexes" sensu Mai \& Walther 1978) in Europe. Fm. = Formation.

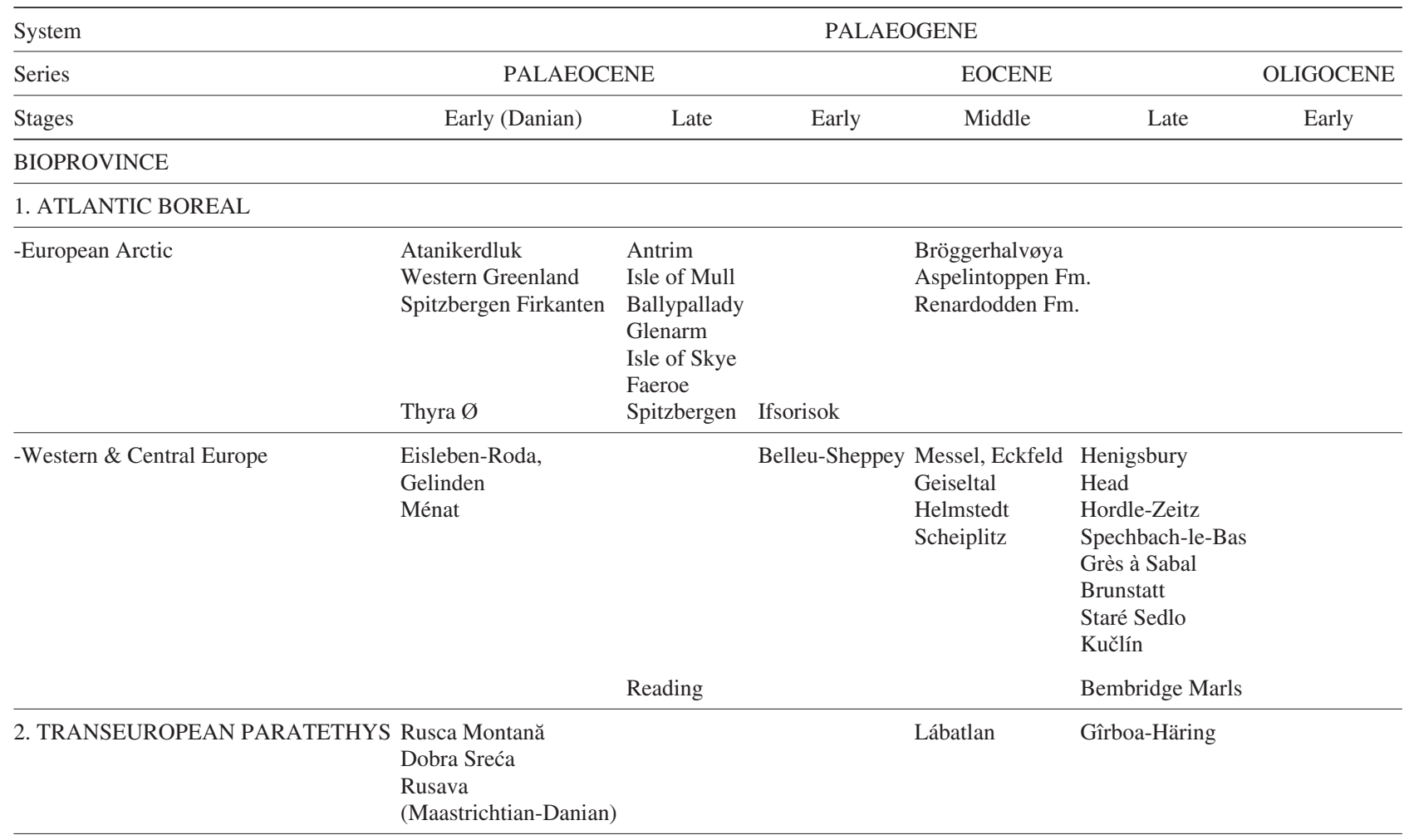

3. EASTERN EUROPE Kamyshin

\begin{tabular}{lcc} 
& Volhynian & Amber - "Blaue Erde" \\
\hline 4. MEDITERRANEAN TETHYS & Montebolca & Célas \\
\hline
\end{tabular}

Germany, where several enigmatic leaf morphotypes are known besides perhaps more accurately recognizable Comptonia, Myrica, Boehmeria and Araliaceae (Friedrich 1883). Much more reliable are taxa based on fruits and seeds (Knobloch \& Mai 1986, Mai 1995), which belong to Theaceae (Eurya, Palaeoschima, Protovisnea), Hamamelidaceae (Exbucklandia, Klikovispermum), Saurauia, Mastixiopsis, Iodes, Juglandaceae (Caryanthus, Platycarya); some ancient elements survived from the Cretaceaous (e.g., Walbeckia, Barclayopsis, Laramisemen). The florulas from Roda, and adjacent Schwarze Mina are similar. The dating relies on the pollen zones (Krutzsch 1967).

The famous but yet unrevised Gelinden flora (Saporta \& Marion 1873, 1878) is mostly known as a foliage assemblage dominated by extinct Fagaceae of the Ushia and Dryophyllum-type, Platanaceae (Dewalquea - Kvaček et al. 2001) and extinct Macclintockia that connects this site with the Arctic. Many broad-leaved morphotypes remain enigmatic. Palms and a few conifers (Pinus, Cupressaceae) have been indicated.

The Ménat unit includes the type locality, Ménat,
France (Laurent 1912, Piton 1940), which is noteworthy by an association of Platanus schimperi - Quercus subfalcata, and the extinct Palaeocarpinus-Craspedodromophyllum plant (Betulaceae; Crane 1981, 1989). Juglandaceae - Casholdia (Crane \& Manchester 1982) and a Sassafras-like morphotype are known. Similar plant assemblages occur at Sézanne (France), Gonna-Walkmühle (Germany) as well as the Herne Bay and Woolwich beds (England) typical of a mixture of temperate extinct elements (Ulmaceae, deciduous Quercus, Cercidiphyllaceae, Juglandaceae) and palaeotropical elements (Icacinaceae, Symplocaceae, Theaceae, Lauraceae, Steinhauera, etc. see Mai 1995).

The latest Palaeocene Reading flora in southern England (for dating see Collinson et al. 2003) shares similar aspects with Ménat and also many elements, e.g. Platanus schimperi, Sassafras - like "Lauraceaephyllum stenolobatus", Nyssidium-Trochodendroides (Crane 1978), Palaeocarpinus-Craspedodromophyllum (Crane 1981), Casholdia (Crane \& Manchester 1982). Many elements from the Reading and Woolwich formations have been based on 
carpological material as summarized by Chandler (1961a, 1964), where Lauraceae, Icacinaceae, Mastixiaceae and Theaceae are well documented. Collinson \& Crane (1978) added Rhododendron. Floras from the Riestedt and Bornstedt basins in Germany, where new elements appear (Carya, Dryophyllum sprengelii, Actinodaphne germariFriedrich 1883, Walther in Mai \& Walther 1985, Mai 1995) are also assigned to the same unit.

The Early Eocene London Clay flora has been assigned to the unit Belleu-Sheppey (Mai 1995). It is the richest Palaeogene assemblage in Europe (Reid \& Chandler 1933; Chandler 1961a, 1964, 1978; Collinson 1983) comparable only with the Middle Eocene Nut Beds flora in Oregon (Manchester 1994). Most elements are based on pyritized fruits and seeds collected at several sites along the southern coast of England. The flora is poor in conifers (Quasisequoia, and some other extinct $\mathrm{Cu}-$ pressaceae, Doliostrobus, Cephalotaxaceae, Pinus) but extremely rich in angiosperms. Only a smaller part of elements can be assigned to modern genera. Collinson (1983) analyzed the present status of the flora and issued floral lists of individual sites - Sheppey, Bognor, Herne Bay and a few others.

Representatives of over 150 genera are treated by her and assigned to mostly subtropical and tropical families, such as Anacardiaceae, Annonaceae, Arecaceae, Burseraceae, Cornaceae, Dilleniaceae, Euphorbiaceae, Flacourtiaceae, Icacinaceae, Lauraceae, Lythraceae, Magnoliaceae, Menispermaceae, Nyssaceae, Ranunculaceae (Pigg \& DeVore 2005), Rhizophoraceae, Rutaceae, Sabiaceae, Sapindaceae, Sapotaceae and Vitaceae. A few elements, such as Cupressaceae, Cercidiphyllaceae, Platanaceae and Fagaceae are documented by permineralized wood (Collinson 1983). Many genera are extinct but some are still extant, e.g. South African Curtisia (Manchester et al. 2007b). There is almost no information about fossil angiosperm foliage for floras of this age. Slightly younger sites in Alum Bay (leaf beds with mostly leaf impressions) provided only limited taxonomic information (Crane 1977).

The Belleu flora in France (Watelet 1866, Frittel 1924) is preserved also as leaf impressions and requires taxonomic revision. According to the illustrations, besides conifers (Doliostrobus?), only Comptonia, large-leaved probably evergreen Fagaceae, Lauraceae and some more enigmatic morphotypes can be recognized.

The Middle Eocene unit Messel-Selsey (Mai 1995) is typified by two floras - Selsey in England and Messel in Germany and includes also the sites at the Alum Bay, Boscombe and Bournemouth in England, floras in the Paris Basin and Geiseltal, Eckfeld and Helmstedt in Germany. The late Early-Middle Eocene Selsey flora (Chandler 1961b) and other assemblages from Bracklesham Bay in England are prevailingly herbaceous including Nypa,
Limnocarpus, Selseycarpus (Collinson 1996) and Cyclanthus (Smith et al. 2008). Woody elements are rare - Doliostrobus (Araucarites selseyensis - Chandler 1961b), extremely rare cones of Pinus, Menispermaceae, Rutaceae, mastixioids and Theaceae (Collinson 1996). More diverse elements are represented by the carpological material from the Lower Bagshot flora of Dorset (Chandler 1962) and the Bournemouth - Boscombe floras in the Hampshire Basin (Chandler 1963). Besides macrofossils of conifers (Araucarites sensu Chandler $=$ Doliostrobus - Bůžek et al. 1968 , Cupressistrobus sensu Chandler = Chamaecyparites Kvaček 1971, Sequoia sensu Chandler = Quasisequoia Kunzmann 1999) and palms a great variety of subtropicaltropical woody dicots of the families Moraceae, Menispermaceae, Altingiaceae (Protoaltingia sensu Chandler = Steinhauera - Mai 1968), Magnoliaceae, Annonaceae, Lauraceae, Icacinaceae (Natsiatum sensu Chandler $=$ Palaeohosiea - Kvaček \& Bůžek 1995), Theaceae, Flacourtiaceae, Nyssaceae, Cornaceae, Clethraceae, Symplocaceae and others have been indicated.

The Alum Bay and Bournemouth leaf assemblages, which yielded compressions with preserved cuticles, are still not fully known in respect of taxonomical composition (Crane 1977, 1978) because fossils leaves of uniform morphology have rarely preserved epidermal features and even then their affinities remain obscure. The pioneer studies by Bandulska (1923, 1924, 1926, 1928, 1931) were complemented by new information (Crane 1978) and revised by subsequent epidermal studies in other Eocene floras (Rüffle 1976, Rüffle et al. 1976, Rüffle \& Jähnichen 1976, Mai \& Walther 1985, Wilde 1989, Knobloch et al. 1996, etc.). Important index fossils were identified by Bandulska, like Doliostrobus (Araucarites goeppertii sensu Bandulska), Rhodomyrtophyllum (Rhodomyrtus sinuata sensu Bandulska), Dicotylophyllum spiculatum (?Stemonurus), "Nothofagus" stopesae, Laurophyllum hirsutum, L. syncarpifolium (Litsea bournensis Bandulska and Cinnamomum wonnacottii Bandulska) and others.

The Middle Eocene site Messel in Hesse (Collinson 1982, 1986, 1988; Wilde 1989, 2004, 2005; Collinson et al. 2010) is by far the most promising, the material is well preserved, but unfortunately still not entirely documented. The flora includes a few conifers (e.g., Doliostrobus, Cephalotaxus), various dicots with predominant Lauraceae and abundant Palmae. Taxonomic studies of the Messel assemblage have recently progressed considerably and include studies of Rutaceae (Collinson \& Gregor 1988), Juglandaceae (Manchester et al. 1994), Cedrelospermum (Ulmaceae, Wilde \& Manchester 2003), Araceae (Wilde et al. 2005), Anacardiaceae (Manchester 1994) including Anacardium (Manchester et al. 2007a), Cyclanthus (Cyclanthaceae, Smith et al. 2008), and additional groups (Collinson et al. 2010). A similar but less diversified flora is preserved in the same sedimentary setting of a maar lake 


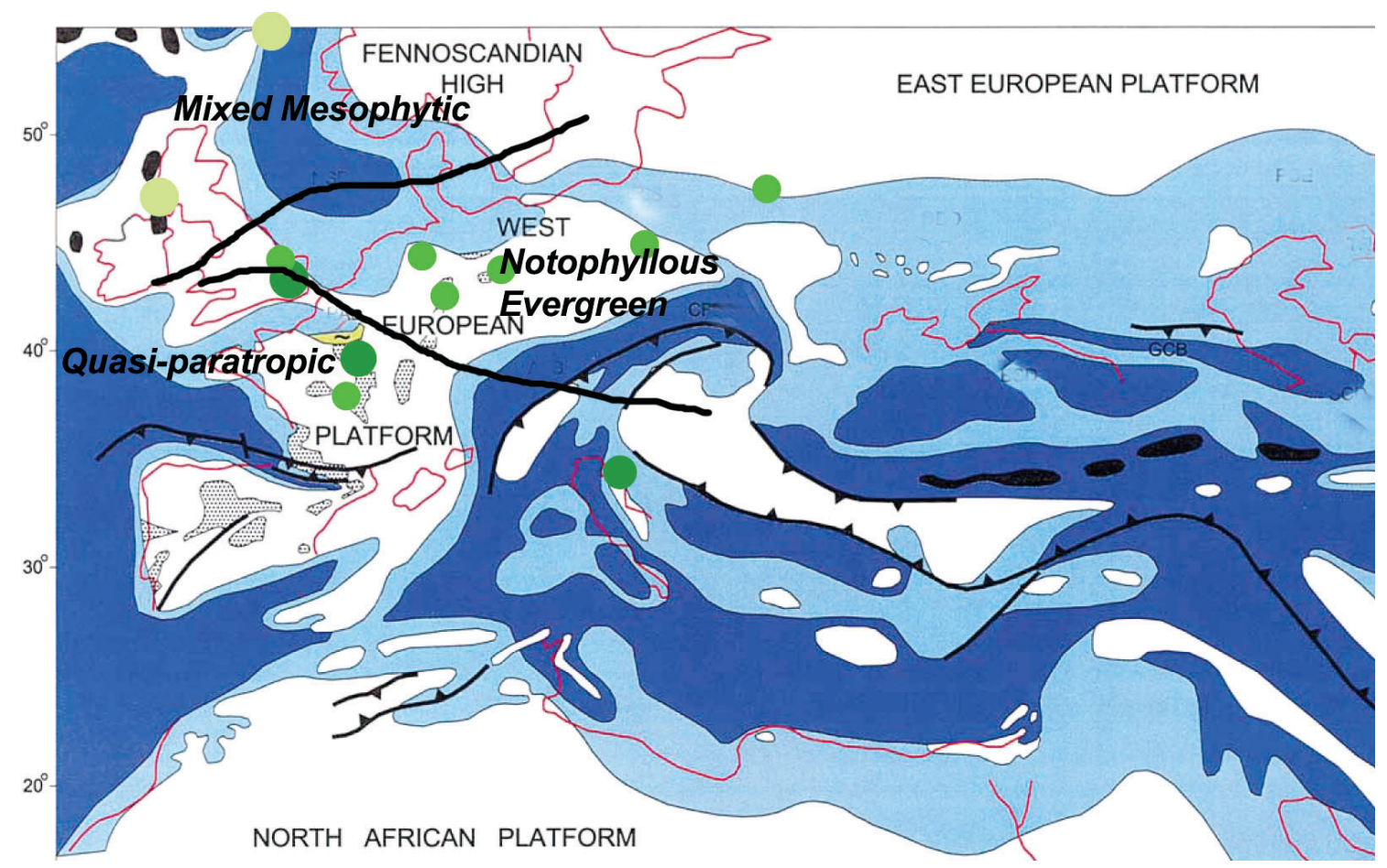

Figure 1. Phytogeographical map of the European Early-Middle Eocene indicating boundaries between polar deciduous, subtropical evergreen and quasi-paratropical forests.

deposit at Eckfeld (Wilde \& Frankenhäuser 1998). It shares the ferns Osmunda, Lygodium, Acrostichum, and "Rumohra", as well as Juglandaceae (e.g., Hooleya, Frankenhäuser \& Wilde 1994) with Messel but differs by the abundance of Comptonia (Wilde \& Frankenhäuser 1999), the enigmatic spiny leaves of Pungiphyllum (Frankenhäuser $\&$ Wilde 1995), and Canarium, the rare occurrence of conifers (Tetraclinis) and Lauraceae, and the lack of Doliostrobaceae, Fagaceae, Rhodomyrtophyllum and others.

The Middle Eocene part of the Geiseltal section in Germany including the coal seams (Barthel 1976, Mai 1976, Rüffle 1976, Rüffle \& Jähnichen 1976, Rüffle et al. 1976) is now separated into the Scheiplitz unit (Mai \& Walther 1983, 2000) together with the type localities Scheiplitz and Dörstewitz. The fern-like cycad Eostangeria (Barthel 1976) is important, occurring with its vicarious relative in the Eocene of North America (Kvaček \& Manchester 1999), the earliest occurrence of Eotrigonobalanus (Kvaček \& Walther 1989) associated with other extinct Fagaceae of the Dryophyllum-type, various Lauraceae, Theaceae (Gordonia, Schima, Ternstroemites), Myricaceae and Myrtaceae (Rhodomyrtophyllum) as well as various Palmae (Mai \& Walther 2000).

The Helmstedt brown-coal flora was first reported by Wilde (1989). The macrofossil spectrum includes common Doliostrobus, typical Eocene plants including Laurophyllum syncarpifolium, ?Stemonurus, Apocynophyllum echitiforme, cf. Dryophyllum album and Sterculia labrusca.
In the periphery of the Weisselster Basin, two floras Dörstewitz and Scheiplitz typify the Floral Assemblage Scheiplitz (Mai \& Walther 2000), which deviates from the previous one by predominantly xeromophic narrow and small-leaved Lauraceae, Fagaceae besides Pinus, Doliostrobus, Comptonia and palms.

The Middle Eocene sites near and within Paris (Trocadero, Puteau, Mont Rouge - Saporta 1879, Watelet 1866) are noteworthy by the occurrence of the xeromophic Tetraclinis brachyodon and Comptonia schrankii (syn. $C$. dryandrifolia). The flora is so far very inadequately known (Ottelia parisiensis Saporta, 1879, Nerium parisiense Saporta, 1879) and requires a new revision. Sabalites, Nypa, Sterculia labrusca, and various enigmatic Lauraceae and evergreen Fagaceae are present.

The late Middle to Late Eocene unit Hordle-Zeitz reflects a lowering of diversity and the proportion of subtropical-tropical elements (Collinson \& Hooker 1987, Mai 1995) due to climatic deterioration. The unit comprises besides type sites Hordle in England and Zeitz in Germany also many others, such as Hengistbury Head, Mudeford in the Hamsphire Basin (Chandler 1963, 1964), several sites in the Loire Basin, the so-called "Grès à Sabal" (Frittel 1922), Staré Sedlo flora in NW Bohemia (Knobloch et al. 1996) and a number of individual sites in the Weisselster Basin and its periphery (Mai \& Walther 1985, 2000).

Mai \& Walther (2000, p. 45) characterize this unit as evergreen notophyllous vegetation type with some 
members of the tropical families and a few predominant elements, like Quasisequoia coutsiae, Doliostrobus taxiformis, Rhodomyrtophyllum reticulosum, Eotrigonobalanus furcinervis, Symplocos kirstei, Retinomastixia glandulosa, Sterculia labrusca and Epacridicarpum sp. div. Further characteristic elements of this unit, partly new immigrants are: Actinodaphne pseudogermari, Becktonia hantonensis, Eomastixia bilocularis, Ficus lucida, Gordonia saxonica, G. minima, Laurophyllum syncarpifolium, L. hirsutum, Mastixicarpum crassum, Nyssa oviformis, Platanus neptuni forma fraxinifolia, Saurauia crassisperma, Steinhauera subglobosa, Sterculia subovoidea, S. labrusca, Ternstroemia bartonensis. Newly recognized are Taxodium, Glyptostrobus and some partly deciduous dicots - Ampelopsis, Carya, Cephalanthus, Pentapanax, Sambucus, Trigonobalanopsis and others (Mai \& Walther 2000). Dating is based mainly on pollen phytostratigraphy - Pg zones 17 and 18 sensu Krutzsch et al. (1992).

The Bembridge-Spechbach unit includes sites at or near the Eocene-Oligocene boundary. The most prominent floras of this time interval are undoubtedly those of the Bembridge Marls (including the Insect Limestone) and the immediately underlying Bembridge Limestone (Reid \& Chandler 1926; Collinson 1983, 1992; Collinson et al. 2010). The Insect Limestone is dated to the very latest Eocene (Hooker et al. 2007, 2009; Collinson et al. 2010). The floristic content is predominantly aquatic herbaceous (Typha-Acrostichum association sensu Collinson 1983). Yet noteworthy arboreal elements are preserved in the Insect Limestone - Doliostrobus, Hooleya, Engelhardia (Palaeocarya), Apocynospermum, and Raskya (Manchester \& Hably 1997) besides Lauraceae, Ziziphus, Palibinia and some more obviously woody dicots (Mai 1995).

The sites Spechbach-le-Bas, Brunstatt and other floras in Alsace belong to the same units according to Mai (1995). He also maintains the same position for a classical site Kučlín in North Bohemia (Ettingshausen 1866, 1868, 1869). The latter flora is much more diversified and shares several elements with that of Bembridge (Doliostrobus, Apocynospermum, Hooleya, Engelhardia, Ziziphus) but differs in a number of elements common to the previous units including Eotrigonobalanus, Palaeohosiea, Platanus neptuni, Cedrelospermum, Sloanea and others of the Eocene-Early Oligocene floras in the Paratethys provinceAilanthus, "Acer" sotzkianum (Kvaček 2002b).

\section{Transeuropean Paratethys Bioprovince}

Early Palaeogene sites are in this area very scanty. Only three units have been recognized: one Palaeocene called Rusca Montana - Rusava and two Eocene: Lábatlan and Gîrbou - Häring. The site Rusca Montana in Transylvania has not been revisited since the last account by Petrescu \&
Dușa (1980). It has been assigned to the Danian by some authors (Baikovskaya 1965; Givulescu 1966, 1968; Mai 1995 ) but to the Maastrichtian by others (Petrescu \& Dusa 1970, 1980; J. Kvaček \& Herman 2004). The flora has been the focus of interest of several palaeobotanists (Tuzson 1913, 1914; Baikovskaya 1965; Givulescu 1966, 1968) because it shares some noteworthy plants with the late Cretaceous flora of Grünbach, namely Sabalites longirachis and Pandanites trinervis (J. Kvaček \& Herman 2004). Gleichenoid ferns and platanoid dicots stress also the connection with the floras of Grünbach and South Bohemian Upper Cretaceous (Herman \& J. Kvaček 2007). The peculiar morphotype assigned to Proteophyllum decorum connects the flora with the Cenomanian of the Czech Republic. Another site Dobra Sreća, eastern Serbia (Pantić \& Nikolić 1955) belongs according to Mai (1995) to the same unit because of its ancient flora (Aenigmatophyllum, Dryophyllum, Dewalquea, Myrtophyllum, Credneria a.o.).

The carpological assemblage of Rusava, Soláň Formation in the flysh of South Moravia (Knobloch \& Mai 1986) dated into Maastrichtian to Danian is rich in ancient extinct elements documented by Klikovispermum (Hamamelidaceae), Valvaecarpus (Cyrillaceae), Caryanthus (Juglandaceae), Protovisnea, Palaeoschima (Theaceae) and rare modern genera (e.g. Boehmeria, Eurya).

The Middle Eocene unit Lábatlan is developed mainly in Hungary. The type locality Lábatlan in the Dorod-Tata basin (Kovács 1961) shares a few elements with Messel, namely Phoenicites, a Pterospermum-like Malvaceae ("Byttneria" apiculata or Byttneriophyllum sensu Wilde) and a legume ("Eucalyptus" sensu Kovács), but affinities of most of the leaf fossils remain doubtful. Poorly preserved cuticles suggest occurrence of Juglandaceae foliage instead of Fagaceae (Knobloch et al. 1996) and the affinity is corroborated by a co-occurring Carya-like fruit (Z. Kvaček, personal observation). Much more diversified floras are in the Tatabánya brown-coal basin. Most of the elements are widely distributed elsewhere in Europe, including Eotrigonobalanus, various Palmae including Nypa, Engelhardia (Palaeocarya), and Ziziphus. A new site Csordakút (Erdei \& Rákosi 2009) includes Daphnogene, cf. Eotrigonobalanus, Cedrelospermum, Myrica and Comptonia, legumes, Ziziphus, Sloanea and Smilax. The revision of several other preliminarily studied floras (Andreánszky 1955, Kovács 1968) is needed (see Hably 1985, 2006). The nearest relations are probably with the next unit Gîrbou - Häring (Erdei \& Rákosi 2009) and Selsey-Messel (Mai 1995, p. 383).

The Late Eocene (to earliest Oligocene) unit Gîrbou Häring is rather heterogenous and not well characterized. Mai (1995) stresses its subxerophilous aspect valid at least for some sites. The leaf impression flora of Gîrbou in Transylvania, Roumania (Petrescu et al. 1976, Petrescu \& Givulescu 1987) is dominated by legumes including a large-leaved Dolichites (=Dioclea sensu Petrescu et al.), 
evergreen Fagaceae (?Eotrigonobalanus, ?Trigonobalanopsis), Lauraceae and includes also Acrostichum, Ziziphus, Comptonia schrankii and ?Pungiphyllum ("Ilex" praeaquifolium Petrescu et al., 1976). The lack of cuticles prevents a more exact characterisation, though a domination of sclerophyllous and subhumid elements is obvious.

The classic site Häring in Tyrol, Austria (Ettingshausen 1853, Butzmann \& Gregor 2002) bears partly subxerophilous character as well, expressed by Tetraclinis brachyodon, a variety of legumes (incl. Mimosites haeringianus) and various partly small-leaved so far enigmatic dicot morphotypes. Conifers (Doliostrobus, Chamaecyparites, Pinus) and palms are common. Identifiable dicots belong to Engelhardia (Palaeocarya), Comptonia schrankii, Myrica longifolia, Ziziphus, Daphnogene, Cedrelospermum, and Ailanthus, many morphotypes should be still taxonomically resolved. In my opinion recently indicated Taxodium balticum, Buxus egeriana, Nyssa altenburgensis, and Apocynophyllum helveticum (Butzmann \& Gregor 2002) are misidentifications. Besides the assemblage from the bituminous limestone Ettingshausen (1853) illustrated a few large-leaved morphotypes (Lauraceae, Eotrigonobalanus) collected in another layer close to the coal seam. The two different aspects of the Häring flora are easily explained by a different habitat and substrate.

Several other sites with a similar aspect have been described from Bulgaria at Mesta Graben (Palamarev et al. 1999), in the Rhodopes (Palamarev \& Petkova 1975, Černjavska et al. 1988), Serbia (Pantić \& Mihajlović 1985, Mihajlović 1985), and Macedonia (Mihajlović \& Ljubotenski 1994). According to Palamarev (1973) a carpoflora from Rudnik near Burgas has clear relations to the Eocene of Geiseltal and England because of noteworthy elements Palaeonymphaea, Becktonia, Stephania, Gironiera, Zanthoxylon, Iodes and Burtonella besides various evergreen Lauraceae and Fagaceae. New biostratigraphic data (R.F. Sachsenhofer, personal communication) assigned also the Socka Beds at least partly to the Late Eocene, namely the classic site, from where the famous Socka flora was described (Unger 1850). Recent revisions indicate the presence of Doliostrobus (Kunzmann 1999), Tetrapteris (Hably \& Manchester 2000), and Sloanea (Hably \& Kvaček 2008) but the flora requires a full revision. There are more elements in common with the Early Oligocene Tard Clay floras in Hungary (e.g. Hably 1979, Kvaček \& Hably 1998) and also the latest Eocene floras in the Boreal province ("Acer" sotzkianum at Kučlín).

\section{Eastern Europe}

As stated by Mai (1995), sites with macrofloras in the East European early Tertiary are scanty and afford a small addition to the floral evolution, although they were used to in- crease the resolution of transcontinental floral development in general [Kryshtofovich (1955 - for discussion on the Poltava type flora see Zhilin (1989)]. For the late Palaeocene-Middle Eocene, the Kamyshin type flora [or Ushia unit sensu Zhilin (1986)] is important and can be characterised by variable foliage of Ushia, Lauraceae and Dewalquea gelindensis. Noteworthy is an endemic plant Oxycarpia bifaria interpreted as Nothofagus-like cupules (Krassilov et al. 1996). The Eocene Volhynian (Drevlyany) unit in Ukraine contains Doliostrobus, Pinus, Macclintockia, Eotrigonobalanus, Comptonia schrankii, palms including Nypa and is hardly differentiated from the contemporaneous floras in Western Europe (Mai 1995). The Late Eocene-Early Oligocene Baltic unit represents the famous "Amber Flora" from the Baltic "Blaue Erde". More than 700 plant species have been described (e.g. Conwentz 1886, 1890; Czeczott 1961) but a full interpretation is still not available. The source of amber could be a conifer, but putative "Pinus succinifera" recently has been rejected (Mai \& Schneider 1988). Fagaceae and palms are commonly reported besides a number of other angiosperm families based on flowers. The main collection was destroyed during the Second World War.

\section{Mediterranean Tethys Bioprovince}

In the South European area Mai (1995) recognized only two units - the Early-Middle Eocene Montebolca unit and the latest Eocene Célas unit. Leaf epidermal studies have not been carried out at any of the sites and most of the floristic data are based on leaf impressions.

The unit Montebolca is typified by the Ypresian site of Monte Bolca (Mons Bubulca), north of Verona in Italy. This site is a world "Lagerstätte" known particularly for fish fauna (Bellwood 1996), large fossils of palms and large-leaved dicot morphotypes the affinities of which are still equivocal. Mai (1995) lists presence of palms, legumes and probable representatives of Myrtaceae, Bombacaceae, Sterculiaceae, Moraceae, Myricaceae, among identifiable elements also Doliostrobus, Ziziphus, Dombeyopsis and various lauroids, partly scattered in other sites in northern Italy near Verona. The second site of this unit is Monte Promina (today Siverič) in Croatia (Ettingshausen 1855), from where a similar plant assemblage with Doliostrobus, Daphnogene, Comptonia schrankii, Myrica longifolia, Ziziphuis ziziphoides, Sterculia labrusca and other, mostly unidentifiable, morphotypes are known. Noteworthy is the occurrence of Nelumbo and various ferns. Mihajlović (1990) considers this type of subxerophyllous floras to be generally distributed in the Tethys phytogeographical province during the Eocene-Early Oligocene. The unit Célas is typified by impression flora of Célas in the Alés Basin in southern France (Laurent 1899). The dominant el- 
ement is a variable large-leaved malvalean morphotype assigned as a rule to Ficus ("Ficus" marionii) or some other genera. Other elements typical of Late Eocene-Early Oligocene floras in southern Europe are present - Comptonia schrankii, Ziziphus ziziphoides, Ailanthus, Engelhardia (Palaeocarya), legumes and other partly enigmatic morphotypes ("Ilex" pachynervis, "Dodonea" saportana). Célas is the type locality of Doliostrobus, Doliostrobaceae (Kvaček 2002a), which is a very typical conifer rarely crossing the Eocene-Oligocene boundary (e.g. Tard Clay in Hungary, Mera in Roumania), being replaced in the terminal Eocene by other conifers elsewhere (e.g. by Juniperus at Čermníky in North Bohemia - Kvaček 2002c). Mai (1995) maintains that the flora of Sarreal/Tarragona in Spain (Fernandez-Marron 1973a, b; Hably \& FernandezMarron 1998) belongs to the same unit and possesses similar significance.

\section{Vegetation reconstructions}

\section{Zonal vegetation}

Polar deciduous to mixed mesophytic forest. - The coldest assemblages correspond to the polar deciduous to mixed mesophytic forest, as exemplified by the Eocene assemblages of Spitsbergen and Isle of Mull within the Brito-Arctic Igneous Province. This formation is characterized by a dominant broad-leaved deciduous component, usually with a large size of the leaf lamina, with rare Ginkgo and mesophytic conifers - Amentotaxus and extinct cupressoids.

The Isle of Mull assemblages (Boulter \& Kvaček 1989) are dated on the boundary between Palaeocene and Eocene. Two of them are partly mesophytic. That from Ardtun comes from the massive lowermost bed of fossiliferous limestone (basal leaf bed sensu Gardner 1887). According to Boulter \& Kvaček (1989), in this assemblage Corylites (probable foliage of Palaeocarpinus) and Trochodendroides (probable foliage of Nyssidium), both deciduous, predominate. Also additional components are mostly deciduous (e.g., Davidoidea, Camptodromites, Juglandiphyllites, and Fagopsiphyllum). Some probably belonged to the riparian intrazonal plants, e.g., Platanites, Vitiphyllum). Gymnosperms are represented by deciduous Ginkgo and evergreen Amentotaxus and others, all much less frequent than deciduous woody eudicots. The latter are mostly of doubtful affinities and over $90 \%$ of the components are hardly assignable to the modern genera form. Another more or less mesophytic plant assemblage comes from Ballypalady, Ireland. It is dominated by conifers, particularly Pinaceae and cupressoids. Among arborescent dicots, the deciduous component prevails: cf. Platanus (Glandulosa) neptuni, Ushia and Camptodromites (Boulter \& Kvaček 1989, p. 126).
The Spitsbergen assemblages (Schweitzer 1974; Budantsev 1983; Kvaček \& Manum 1993, 1997; Golovneva 2000, 2002 etc.) are of early Palaeocene to late Eocene age. Those from the Sturvola (= Aspelintoppen) Formation are Early Eocene in age and are included here. Several local sites are assigned to this formation (Kvaček et al. 1994, table 2) and in general composition they are similar each other. The more or less mesophytic component of the plant assemblages includes Ginkgo, Ushia, Corylites, Craspedodromophyllum and Aesculus, to name the most characteristic plants, while Metasequoia, trochodendroids and ulmoids belong to the intrazonal part. The components are prevailingly broad-leaved deciduous and mostly show distant or quite unknown affinities to modern genera with rare exceptions.

Mid-latitude notophyllous broad-leaved evergreen forest. This forest type is best documented at Hordle, England (late Eocene), Eckfeld in Germany (Middle Eocene), less completely at Lábatlan in Hungary (Middle Eocene) and Kučlín in north Bohemia (late Eocene). It is characterized by dominating Lauraceae, common Juglandaceae, Ulmaceae (Cedrelospermum), Malvaceae ("Ficus" daphnogenes, "Byttneria" apiculata), Leguminosae, rare conifers (Tetraclinis, partly azonal Doliostrobus, Cephalotaxus) and various accessory exotic and extinct elements (e.g., Pungiphyllum, Ailanthus, Sloanea, Icacinaceae, Menispermaceae, Vitaceae). The foliage size category is noto- to microphyllous.

The late Eocene diatomite Kučlín in North Bohemia (Kvaček 2002a) differs in new immigration of Platanus (Glandulosa) neptuni (Kvaček \& Manchester 2004), Raskya (Manchester \& Hably 1997) but sharing with Messel a number of extinct plants (e.g,. Doliostrobus, Hooleya, "Ficus" daphnogenes). The drawback of this classical site is poor preservation of leaf fossils representing impressions without cuticles. Zonal parts of the Zeitz flora (Mai \& Walther 1985, 2000), rich in mastixioids, undoubtedly belong to this formation, although it may be that many elements are riparian (see below).

Mid-latitude quasi-paratropic rain forest. - The best documented vegetation of this type is known from the Early Eocene London Clay fruit and seed flora (Collinson 1983). The considerable part of this highly allochthonous assemblage can serve for mesophytic components. The forest can be characterized, as suggested by Collinson (1983) by polydominating families Annonaceae, Cornaceae, Icacinaceae, Lauraceae, Menispermaceae, Palmae, Rutaceae, Vitaceae etc. Conifers are rare - Tetraclinis?, Doliostrobus?, Quasisequoia?, various mesophytic components, mostly with tropical affinities are present: Annonaceae, Lauraceae, Cornaceae, Flacourtiaceae, Icacinaceae, Menispermaceae, Vitaceae and some Palmae. 
Mai (1995) and Wilde (2005) also considered the Messel flora to be paratropical due to floristic composition (abundant Araceae, palms). However, the notophyllous size category prevails among partly evergreen (most Lauraceae, Myrtaceae) and partly deciduous woody dicots (Ulmaceae, Araliaceae), contrary to the comparable paratropical vegetation, e.g. in Hainan and elsewhere in Southeast Asia, today.

Probably a paratropical kind of vegetation is reflected in the large-leaved Early Eocene Belleu assemblage from Paris environs (Watelet 1866), which is unfortunately little documented taxonomically. Foliage size category is macrophyllous to notophyllous.

Whether or not the Early Eocene assemblage of Montebolca (Mai 1995) belongs to this category is doubtful, although quite logical. The collections from this site require revisions.

\section{Eocene Intrazonal vegetation}

Polar coal-forming and riparian deciduous forest. - This is particularly known from Spitsbergen (Aspelintoppen Fm. and Renardodden), also a part of the Mull assemblage consists of intrazonal elements. Swamp conifers - Metasequoia, Taxodioideae and some broad-leaved deciduous obviously intrazonal angiosperms (e.g., Trochodendroides-Nyssidium and $\mathrm{Zi}$ zyphoides-Nordenskioeldia), characterize the forests.

In the Mull assemblage, coal-forming elements are represented by a taxodioid conifer Elatocladus, broad-leaved platanoids, trochodendroids and probably also Vitaceae. In Spitsbergen, the dominating conifer is Metasequoia in combination with trochodendroids and probably Ulmaceae and Acer arcticum.

Broad-leaved evergreen riparian gallery forest with palms. - The intrazonal Eocene forest of the subtropical zone in mid-latitudinal Europe belongs to this type. Such plant assemblages are mainly connected with the sandy facies. They are widely distributed in the Late Eocene from Loire (Grès à Sabal), to Germany (Zeitz, upper part of the Geiseltal section), Bohemian Massif (Staré Sedlo Formation) to Eastern Europe (Mogilno, Pasekovo etc.).

The forest is characterized by dominating evergreen Fagaceae (Eotrigonobalanus and others) and Lauraceae (Daphnogene cinnnamomea and others). Common are Altingiaceae (Steinhauera), Theaceae (Gordonia), Rhodomyrtophyllum, Populus, sabaloid and calamoid palms. Conifers belong mostly to the taxodioid and sequoioid Cupressaceae, partly to Doliostrobaceae (Doliostrobus). Characteristic examples of this type of intrazonal riparian forests belong to the Zeitz unit (Mai \& Walther 1985, 2000) and extend from north Bohemia to Saxony.
In Bohemia, it is distributed in the Sokolov and Cheb Basins and is well known as the Staré sedlo type (Knobloch et al. 1996). The plant-bearing layers contain abundant impressions of Eotrigonobalanus, Daphnogene, infructescences of Steinhauera, sabaloid and calamoid palms. Additional rare accessory elements include tree ferns, broad-leaved Gordonia, Populus, Majanthemophyllum etc.

Mixed Doliostrobus (and/or Quasisequoia) and broadleaved evergreen swamp forest. - Another type of intrazonal coal-forming vegetation is well known from Germany (Mai \& Walther 1985). The assemblages connected directly with coal swamps are first of all well known from Helmstedt, Scheiplitz, Profen (Middle Eocene). This type of coal-forming vegetation is characterized by giant Doliostrobus and Quasisequoia as main coal-forming trees and subordinate evergreen Lauraceae, Fagaceae, Myricaceae, Ericaceae, sabaloid palms and other swamp plants (Mai \& Walther 1985, 2000; Wilde 1989).

Mixed pine and broad-leaved evergreen swamp forest. This is a special kind of coal-forming vegetation, which is known from the Geiseltal "black" coal (Middle Eocene) and can be characterized as open stands of Pinus as main coal-forming trees and admixture of common evergreen Lauraceae, Fagaceae, Rutaceae, Ericaceae, Sapotaceae, diverse palms, ferns and other swamp plants including aquatic angiosperms (Mai 1976). Interesting is the occurrence of a rare cycad Eostangeria (Barthel 1976).

Mangrove. - This is the final intrazonal forest vegetation type to be mentioned. It is well documented in the London Clay and slightly younger Bracklesham Bay flora (Collinson 1983, 1996), but also by many other occurrences of mangrove palm Nypa elsewhere in Europe (Gee 2009). It is reconstructed as stands of $\mathrm{Nypa}$, with locally common $\mathrm{Ce}$ riops and Palaeobruguiera. Additional notable associated elements are enigmatic Wetherellia, probably related to extant Hypomane (Mazer \& Tiffney 1982). A newly recovered Neotropical monocot Cyclanthus (formerly "Scirpus"lakensis - Smith et al. 2008) may have accompanied freshwater inland margins of mangroves in many Early-Middle Eocene sites.

\section{Extrazonal vegetation}

The Eocene extrazonal vegetation in Europe is poorly known and doubtful. One kind of such forests can be deciphered from the pollen spectra that include documentation of plants not represented in the macrofossil record. Another example of extrazonal vegetation is due to substrate. 
Mountain coniferous forest. - The vegetation cover of mountains can be traced in the pollen spectra from Spitsbergen (Early Eocene), Messel (Middle Eocene), Staré Sedlo (Late Eocene) to name most striking examples. This part of the spectra includes dominating Pinaceae (Pinus, Cathaya, Abies, Tsuga etc. - see a.o. Konzalová in Knobloch et al. 1996). In warmer areas conifers are less diverse, with notable proportion of evergreen Fagaceae. There is no direct evidence of palaeoaltitudinal differentiation in the European Eocene and the above vegetation type is only inferred from an analogous altitudinal differentiation, which is particularly known in mountains of southeast China today.

Xerophytic scrub. - (Sub)xerophytic vegetation probably due to a specific substrate is known from Arcuei, Calcaire Grossier (Early Eocene). It is documented by Tetraclinis brachyodon, sclerophyllous Comptonia schrankii and narrow-leaved dicots with dubious affinities (Watelet 1866). Similar setting can be expected for the site Häring (Austria) on the Eocene-Oligocene transition sharing Tetraclinis brachyodon and Comptonia schrankii but differing in abundant Doliostrobus, and also for a part of the Bembridge Marls flora (Dicotylophyllum pinnatifidum $=$ Palibinia), where xerophytes may have grown on a specific substrate. An important probably shrubby element Ziziphus ziziphoides may also belong here.

\section{Conclusions}

To summarize the distribution of various individual vegetation types, a rough phytogeographical map of the European Early-Middle Eocene (Fig. 1) may indicate boundaries between polar deciduous, mid-latitudinal notophyllous evergreen and quasi-paratropical forests. The boundaries shifted during the Eocene northwards and typical quasi-paratropical forests did not exist within Europe towards the Eocene-Oligocene boundary. The palaeclimatic deterioration in the latest Eocene was expressed variously depending on the latitude/palaeogeography: either within the Nothophyllous Broad-leaved Evegreen Forest (Hungary, England) or in transition from the Nothophyllous Broad-leaved Evegreen Forest to the Mixed Mesophytic Forest (North Bohemia, Saxony).

\section{Acknowledgments}

The author is grateful to the organisers for the invitation to participate in the symposium on Palaeogene floras in Prague, namely Margaret E. Collinson, Melanie L. DeVore and Kathleen B. Pigg, who also helped editing and correcting this paper. The presented reviewed data have been gathered thanks to information provided by Lilla Hably, Boglarka Erdei, Dieter H. Mai, Steven R. Man- chester, Harald Walther, Volker Wilde, Sergey Zhilin, the late Emanuel Palamarev and others. The author also participated in field work in the Czech Republic thanks to the initiative of his late colleagues Čestmír Bůžek, Erwin Knobloch and František Holý. The study was financially supported by the project No. 205/08/0643 of the Grand Agency of Czech Republic.

\section{References}

ANDREÁNSZKY, G. 1955. Neue und interessante Pflanzenarten aus Ungarn. Annales historico-naturales Musei nationalis Hungarici 6, 37-50.

BAIKOVSKAYA, T.N. 1965. O verkhemelovykh rasteniakh Transilvanii [On the Upper Cretaceous plants of Transylvania (Romania)]. Botanicheskii Zhurnal 50, 371-374.

BANDULSKA, H. 1923. A preliminary paper on the cuticular structure of certain dicotyledonous and coniferous leaves from the Middle Eocene flora of Bournemouth. Journal of the Linnean Society London, Botany 46, 241-269.

BANDULSKA, H. 1924. On the cuticles of some Recent and fossil Fagaceae. Journal of the Linnean Society London, Botany 46, $427-441$.

BANDULSKA, H. 1926. On the cuticles of some Recent and fossil Lauraceae. Journal of the Linnean Society London, Botany 47, 383-425.

BANDULSKA, H. 1928. A Cinnamom from the Bournemouth Eocene. Journal of the Linnean Society London, Botany 48, 139-147.

BANDULSKA, H. 1931. On the cuticles of some Recent and fossil Myrtaceae. Journal of the Linnean Society London, Botany 48, 657-671.

BARTHEL, M. 1976. Farne und Cycadeen. Eozäne Floren des Geiseltales. Abhandlungen des Zentralen Geologischen Instituts 26, 439-490.

BELLWOOD, D.R. 1996. The Eocene fishes of Monte Bolca: The earliest coral reef fish assemblage. Coral Reef 15(1), 11-19.

Boulter, M.C. \& KVAČEK, Z.1989. The Palaeocene flora of the Isle of Mull. Palaeontology, Special Papers 42, 1-149.

Boulter, M.C. \& MANuM, S.B. 1989. The "Brito-Arctic Igneous Province" flora around the Palaeocene-Eocene boundary. Proceedings of the Ocean Drilling Program 104B, 663-680.

BOYD, A. 1990. The Thyra Ø Flora: toward an understanding of the Early Tertiary climate and vegetation in the High Arctic. Review of Palaeobotany and Palynology 62, 189-204. DOI 10.1016/0034-6667(90)90089-2

BUDANTSEV, L.Y. 1983. Istoria Arkticheskoi Flory Epokhi Rannego Kainofita [History of the Arctic Flora of the Epoch of the Kenophyticum]. 156 pp. Nauka, Leningrad.

ButZMANN, R. \& GREGOR, H.-J. 2002. Die oligozäne Flora von Bad Häring (Tirol). Teil. I. Documenta Naturae 140, 1-117.

BU゚ŽEK, Č., HOLÝ, F. \& KVAČEK, Z. 1968. Die Gattung Doliostrobus Marion und ihr Vorkommen im nordböhmischen Tertiär. Palaeontographica, Abteilung B 123, 153-172.

CHANDLER, M.E.J. 1961a. The lower Tertiary floras of southern England I. 354 pp. British Museum (Natural History), London.

CHANDLER, M.E.J. 1961b. Post-Ypresian plant remains from the Isle of Wight and the Selsey Peninsula, Sussex. Bulletin of the British Museum (Natural History), Geology 5(2), 13-41.

CHANDLER, M.E.J. 1962. The lower Tertiary floras of southern England II. 176 pp. British Museum (Natural History), London.

CHANDLER, M.E.J. 1963. The lower Tertiary floras of southern England III. 169 pp. British Museum (Natural History), London. 
CHANDLER, M.E.J. 1964. The lower Tertiary floras of southern England IV. 151 pp. British Museum (Natural History), London.

CHANDLER, M.E.J. 1978. Supplement to the Lower Tertiary floras of southern England. Part 5. Tertiary Research Special Papers 4, $1-47$.

COLLINSON, M.E. 1982. A preliminary report on the Senckenberg-Museum collection of fruits and seeds from Messel bei Darmstadt. Courier Forschungsinstitut Senckenberg 56, 49-57.

COLLINSON, M.E. 1983. Fossil plants of the London Clay. Palaeontological Association Field guides to fossils 1. 121 pp. The Palaeontological Association, London.

COLLINSON, M.E. 1986. Früchte und Samen aus dem Messeler Ölschiefer. Courier Forschungsinstitut Senckenberg 85, 217-220.

COLLINSON, M.E. 1988. The special significance of the Middle Eocene fruit and seed flora from Messel, West Germany. Courier Forschungsinstitut Senckenberg 107, 187-197.

COLLINSON, M.E. 1992. Vegetational and floristic changes around the Eocene/Oligocene boundary in western and central Europe, 437-450. In Prothero, D.R. \& BERGgren, W.A. (eds) Eocene-Oligocene climatic and biotic evolution. Princeton University Press, Princeton.

COLLINSON, M.E. 1996. Plant macrofossils from the Bracklesham Group (Early \& Middle Eocene), Bracklensham Bay, West Sussex, England: review and significace in the context of coeval British Tertiary floras. Tertiary Research 16, 175-202.

Collinson, M.E. \& CRANE, P.R. 1978. Rhododendron seeds from the Palaeocene of southern England. Botanical Journal of the Linnean Society 76(3), 195-205. DO1 10.1111/j.1095-8339.1978.tb02361.x

COLLINSON, M.E. \& GREGOR, H.J. 1988. Rutaceae from the Eocene of Messel, West Germany. Tertiary Research 9, 67-80.

COLLINSON, M.E. \& HOOKER, J.J. 1987. Vegetational and mammalian faunal changes in the Early Tertiary of southern England, 259-304. In FRIIS, E.M., CHALONER, W.G. \& CRANE, P.R. (eds) The origin of angiosperms and their biological consequences. Cambridge University Press, Cambridge.

COLLINSON, M.E. \& HOOKER, J.J. 2003. Paleogene vegetation of Eurasia: framework for mammalian faunas. Deinsea 10, 41-83.

COllinson, M., Singer, R.L. \& HoOKER, J.J. 1993. Vegetational change in the latest Eocene of southern England, 81-87. In Planderová, E., KonZÁlová, M., KVAČeK, Z., SitÁr, V., SNOPKOVÁ, P \& SuballyovÁ, D. (eds) Paleofloristic and paleoclimatic changes during Cretaceous and Tertiary, Proceedings of the International Symposium, September 14-29, 1992, Bratislava. Konferencie. Sympozia. Seminare. Dionyz Stur Institute of Geology, Bratislava.

COLlinson, M.E., HoOKER, J.J. \& GROCKe, D.R. 2003. The Cobham Lignite Bed and penecontemporaneous macrofloras of S. England: a record of vegetation and fire across the Paleocene-Eocene thermal maximum. Geological Society of America Special Paper 369, 333-349.

Collinson, M.E., MANCHESTeR, S.M., Wilde, V. \& HAYes, P. 2010. Fruit and seed floras from exceptionally preserved biotas in the European Paleogene. Bulletin of Geosciences 85(1), 155-162. DOI 10.3140/bull.geosci.1155

Conwentz, H. 1886. Die Flora des Bernsteines. 2. Die Angiospermen des Bernsteines. 140 pp. Danzig.

CONWENTZ, H. 1890. Monographie der baltischen Bernsteinbäume. 151 pp. Englemann, Danzig.

CRANE, P.R. 1977. The Alum Bay plant beds. Tertiary Research 1(3), 95-99.

CRANE, P.R. 1978. Angiosperm leaves from the Lower Tertiary of southern England. Courier Forschungsinstitut Senckenberg 30, 126-132.
CRANE, P.R. 1981. Betulaceous leaves and fruits from the British Upper Palaeocene. Botanical Journal of the Linnean Society 83, 103-136.

CRANE, P.R. 1988. Abelia-like fruits from the Palaeogene of Scotland and North America. Tertiary Research 9, 21-39.

CRANE, P.R. 1989. Early fossil history and evolution of the Betulaceae, 87-116. In CRANE, P.R. \& BLACKMORE, S. (eds) Evolution, Systematics, and Fossil History of the Hamamelidae, 2. The Systematic Association Special Volume 40B. London.

CRANE, P.R. \& MANCHESTER, S.R. 1982. Casholdia, an extict juglandaceous fruit from the Upper Paleocene of Southern England. Botanical Journal of the Linnean Society 85, 89-101. DOI 10.1111/j.1095-8339.1982.tb00587.x

CRANE, P.R., MANCHESTER, S.R. \& DILCHER, D.L. 1988. Morphology and phylogenetic significance of the angiosperm Platanites hebridicus from the Palaeocene of Scotland. Palaeontology 31, 503-517.

Černjavska, S., Palamarev, E. \& PetKova, A. 1988. Micropaleobotanical and macropaleobotanical characteristics of the Paleogene sediments in Hvojna Basin (Central Rhodopes). Bulgarian Academy of Sciences, Palaeontology, stratigraphy and lithology 26, 26-36.

CzeczotT, H. 1961. The flora of Baltic amber and its age. Prace Muzeum Ziemi 4, 119-145.

ERDEI, B. \& RÁKosI, L. 2009. The Middle Eocene flora of Csordakút. Geologica Carpathica 60(1), 43-57. DOI 10.2478/v10096-009-0005-4

ETTINGSHAUSEN, C. 1853. Die Tertiaerfloren der Oesterreichischen Monarchie. 2. Tertiäre Flora von Häring in Tirol. Abhandlungen der Kaiserlich-königlichen geologischen Reichsanstalt, Serie. II, Abteilung 3, 2, 1-118.

ETtingshausen, C. 1855. Die eozäne Flora des Monte Promina. Denkschriften der Kaiserlichen Akademie der Wissenschaften, Mathematische-naturwissenschaftliche Klasse 8, 1-28.

ETtingShausen, C. 1866. Die fossile Flora des Tertiärbeckens von Bilin I. Denkschriften der Kaiserlichen Akademie der Wissenschaften, Mathematisch-naturwissenschaftliche Klasse 28, 1-98.

ETTINGSHAUSEN, C. 1868. Die fossile Flora des Tertiärbeckens von Bilin II. Denkschriften der Kaiserlichen Akademie der Wissenschaften, Mathematisch-naturwissenschaftliche Klasse 28, 191-242.

ETTINGSHAUSEN, C. 1869. Die fossile Flora des Tertiärbeckens von Bilin III. Denkschriften der Kaiserlichen Akademie der Wissenschaften, Mathematisch-naturwissenschaftliche Klasse 29, 1-110.

FERNANDEZ-MARRON, M.T. 1973a. Nuevas aportaciones a la systemática y paleoecologia de la flora oligocena de Sarreal /Tarragona). Estudios Geologicos 29, 157-169.

FERNANDEZ-MARRON, M.T. 1973b. Reconstruccion del paleoclima del yacimiento oligocenico de Sarreal (Tarragona) a traves del studio morphologico de los restos foliares. Boletin Real Sociadad Espanola de Historia Natural (Geologia) 71, 237-242.

FRANKENHÄUSER, H. \& WILDE, V. 1994. Zweiflügelige Juglandaceen-Früchte aus dem Mitteleozän von Eckfeld bei Manderscheid (Eifel). Vorläufige Mitteilung. Mainzer naturwissenschaftliches Archiv, Beihefte 16, 143-150.

FRANKENHÄUSER, H. \& WILDE, V. 1995. Stachelspitzige Blätter aus dem Mitteleozän von Eckfeld (Eifel). Abhandlungen des Staatlichen Museums für Mineralogie und Geologie zu Dresden 41, 97-115.

FRIEDRICH, F. 1883. Beiträge zur Kenntnis der Tertiärflora der Provinz Sachsen. Abhandlungen zur Geologischen Specialkarte Preussens 4, 1-305.

FrITTEL, P.H. 1922. Contribution à l'étude des flores tertiaires d'après les materiaux du Muséum d'Histoire Naturelle. V. Flore 
Bartonienne des “Grés à Sabalites”. Bulletin du Muséum national d'histoire naturelle, Série 2, 28, 202-207, 329-332, 385-390, 448-452.

FrITTEL, P.G. 1924. Suite et additions à la révision de la flore cuisienne des grès de Belleu. Bulletin de la Société géologique de France, Série 4, 24, 150-175.

GARDNER, J.S. 1887. On the leaf-beds and gravels of Ardtun, Carsaig, etc. in Mull, with notes by G.A.C. Cole. Quaternary Journal of the Geological Society, London 43, 270-301.

GEE, C.T. 2009. An open-ended discussion on the taphonomy of Nypa fruits. Abstract, the $19^{\text {th }}$ Plant Taphnonomy Workshop, Utrecht.

GIVUlESCU, R. 1966. Sur quelques plantes fossiles du Danian de Roumanie. Comptes Rendus Homdomadaires des Scéances de la Academie des Sciences. Paris, Série D, 262, 1933-1936.

GIVUlESCU, R. 1968. Nouvelles plantes fossiles du Danian de Roumanie. Comptes Rendus Homdomadaires des Scéances de la Academie des Sciences. Paris, Série D, 267, 880-882.

GolovnevA, L.B. 2000: Early Palaeogene floras of Spitsbergen and North Atlantic floristic exchange. Acta Universitatis Carolinae, Geologica 44(1), 39-50.

GolovNEVA, L.B. 2002. Palaeocarpinus (Betulaceae) iz paleogena Shpitsbergena i transatlanticheskie migratsii rastenii [Palaeocarpinus (Betulaceae) from the Paleogene of Spitsbergen]. Paleontologicheskii Zhurnal 2002(4), 97-103.

HABLY, L. 1979. Some data to the Oligocene flora of the Kiscellian Tard Clay, Hungary. Annales historico-naturales Musei nationalis Hungarici 71, 33-53.

HABLY, L. 1985. New data in the Eocene flora of Hungary. Annales historico-naturales Musei nationalis Hungarici 77, 25-33.

HABLY, L. 2006. Catalogue of the Hungarian Cenozoic leaf, fruit and seed floras from 1856 to 2005. Studia botanica hungarica 37 , 41-129.

HABLY, L. \& FERNANDEZ-MARRON, M.T. 1998. A comparison of the Oligocene floras of the Tethyan and Central Paratethyan areas on the basis of Spanish and Hungarian macrofloras. Tertiary Research 18, 67-76.

HABLY, L. \& KVAČEK, Z. 2008. Nomenclatural types and taxonomy of Unger's (1850) and Ettingshausen's (1853) fossil leaves recongized as new Sloanea records in the European Paleogene. Neues Jahrbuch für Geologie und Paläontologie, Abhandlungen 249/2, 139-142. DO] 10.1127/0077-7749/2008/0249-0139

HABLY, L. \& MANCHESTER, S.R. 2000. Fruits of Tetrapteris (Maphigiaceae) from the Oligocene of Hungary and Slovenia. Review of Palaeobotany and Palynology 111, 93-101. DOI 10.1016/S0034-6667(00)00019-1

HEER, O. 1868. Die fossile Flora der Polarländer enthaltend die in Nordgrönland, auf der Melville-Insel, im Bankslůand, am Mackenzie, in Island und in Spitsbergen entdeckten fossilen Pflanzen. Flora fossilis arctica 1, 1-192. Wurster, Zürich.

HEER, O. 1869. Contributions to the fossil flora of North Greenland, being a description of the plants collected by Mr. Edward Whymper during the summer of 1867. Philosophical Transactions of the. Royal Society, London 159, 445-488. DOI 10.1098/rstl.1869.0016

HEER, O. 1870. Die Miozäne Flora und Fauna Spitsbergen. Kungliche Svenska Vetenskapsakademiens Handlingar 8(7), 1-98.

HEER, O. 1874. Nachträge zur miocenen Flora Grönlands. Kungliche Svenska Vetenskapsakademiens Handlingar 13, 1-29.

HEER, O. 1876. Beträge zur fossilen Flora Spitsbergens. Kungliche Svenska Vetenskapsakademiens Handlingar 14, 1-141.

HEER, O. 1880. Nachträge zur fossilen Flora Grönlands. Kungliche Svenska Vetenskapsakademiens Handlingar 18(2), 1-17.

HEER, O. 1883. Flora fossilis Groenlandica. Flora fossilis arctica 7(1), 112 pp., 7(2), 275 pp., Wurster, Zürich.
Herman, A.B. \& KVAČEK, J. 2007. Early Campanian Grünbach flora of Austria: systematic composition and palaeoclimatic interpretation. Acta Palaeobotanica 47(1), 37-55.

Hooker, J.J., Collinson, M.E., Grimes, S.T., Sille, N.P. \& MATTEY, D.P. 2007. Discussion on the Eocene-Oligocene boundary in the UK. Journal of the Geological Society of London 164, 685-688. DOI 10.1144/0016-76492006-098

HoOKER, J.J., Grimes, S.T., MATTEY, D.P., Collinson, M.E. \& SHELDON, N.D. 2009. Refined correlation of the UK late Eocene - Early Oligocene Solent Group and timing of its climate history. Geological Society of America Special Paper 452, 179-195.

KNOBLOCH, E. \& MAI, H.D. 1986. Monographie der Früchte und Samen in der Kreide von Mitteleuropa. Rozpravy Ústředního ústavu geologického 47,1-221.

KnOBloch, E., KonZalovÁ, M. \& KVAČEK, Z. 1996. Die obereozäne Flora der Staré Sedlo-Schichtenfolge in Böhmen (Mitteleuropa). Rozpravy Ústředního ústavu geologického 49, $1-260$.

KoCH, H.E. 1963. Fossil plants from the lower Paleocene of the Agatdalen (Angamårtussut) area, central Nûgssuag Peninsula, northwest Greenland. Grřnlands Geologiske Underšrgelse Bulletin, 1-120.

KoVÁCS, É. 1961. Mitteleozäne Flora aus der Umgebung von Lábatlan. Magyar Állami Földtani Intézet Évi Jelentése 1957-8, 473-495.

KoVÁCS, É. 1968. Études préliminaires sur le flore éocène de Tatabánya (Hongrie occidental). Annales Universitatis Scientiarum Budapestinensis de Rolando Eötvös Nominatae, Sectio Biologica 9-1, 231-240.

Kovar-Eder, J., JechoreK, H., KvaČEK, Z. \& PARAshiv, V. 2008. The integrated plant record to reconstruct Neogene zonal vegetation in Europe. Palaios 23, 97-111 (appendix 1-9 on web: www.paleo.ku.edu/palaios).

Krassilov, V.A., MAKUlBEKOV, N.M. \& MASLOVA, N.P. 1996. Ushia, a Palaeocene angiosperm of Nothofagus affinties from the Lower Volga and Western Kazakhstan. Palaeontographica, Abteilung B, 239, 137-145.

KRUTZSCH, W. 1967. Der Florenwechsel im Alttertiär Mitteleuropa auf Grund von sporenpaläontologischen Untersuchungen. Abhandlungen des Zentralen Geologischen Instituts 10, 17-37.

Krutzsch, W., Blumenstengel, H., Kiesel, Y. \& RÜFFle, L. 1992. Paläobotanische Klimagliederung des Alttertiärs (Mitteleozän bis Oberoligozän) in Mitteldeustchland und das Problem der Verknüpfung mariner und kontinentaler Gliederung (klassische Biostratigraphie - paläobotanisch-ökologische Klimastratigraphie - Evolutions-Stratigraphie des Vertebraten). Neues Jahrbuch für Geologie und Paläontologie Abhandlungen 186(1-2), 137-253.

KRYSHTOFOVICH, A.N. 1955. Razvitie botaniko-geograficheskikh oblastey severnogo polushariya s nachala tretichnogo perioda [Evolution of botanical-geographic areas of the northern hemisphere at the beginning ot the Tertiary period], 825-844 In Voprosy geologii Azii 2. Moscow.

KunZMANN, L. 1999. Koniferen der Oberkreide und ihre Relikte im Tertiär Europas. Abhandlungen des Staatlichen Museums für Mineralogie und Geologie zu Dresden 45, 1-190.

KVAČEK, J. \& HeRman, A. B. 2004. Monocotyledons from the Early Campanian (Cretaceousú of Grünbach, Lower Austria. Review of Palaeobotany and Palynology 128, 323-353.

KVAČEK, Z. 1971. Supplementary notes on Doliostrobus Marion. Palaeontographica, Abteilung B 135, 115-126.

KVAČEK, Z. 2002a. Novelties on Doliostrobus (Doliostrobaceae), an extinct conifer genus of the European Palaeogene. C̆asopis Národního muzea 171, 131-175. 
KVAČEK, Z. 2002b. Late Eocene landscape, ecosystems and climate in north Bohemia with particular reference to the locality Kučlín near Bílina. Bulletin of the Czech Geological Survey 77, 217-236.

KVAČEK, Z. 2002. A new juniper from the Palaeogene of Central Europe. Feddes Repertorium 113, 492-502.

KVAČEK, Z. \& BŮŽEK, Č. 1995. Endocarps and foliage of the flowering plant family Icacinaceae from the Tertiary of Europe. Tertiary Research 15(3), 121-138.

KVAC̆EK, Z. \& HABLY, L. 1998. New plant elements in the Tard Clay Formation from Eger-Kiseged. Acta Palaeobotanica 38, 5-23.

KVAČEK, Z. \& MANCHESTER, S.R. 1999. Eostangeria Barthel (extinct Cycadales) from the Paleogene of western North America and Europe. International Journal of Plant Sciences 160, 621-629.

KVAČEK, Z., MANCHESTER, S.R. \& GUO, S. 2001. Trifoliate leaves of Platanus bella (Heer) comb. $\mathrm{n}$. from the Paleocene of North America, Greenland, and Asia and their relationship among extinct and extant Platanaceae. International Journal of Plant Sciences 162, 441-458.

KVAČEK, Z. \& MANCHESTER, S.R. 2004. Vegetative and reproductive structure of the extinct Platanus neptuni from the Tertiary of Europe and relationships within the Platanaceae. Plant Systematics and Evolution 244, 1-29.

KVAČEK, Z., MANCHESTER, S.R. \& AKHMETIEV, M.A. 2005. Review of the fossil history of Craigia (Malvaceae s.1.) in the Northern Hemisphere based on fruits and co-occurring foliage, 114-140. In AKHMETIEV, M.A. \& HERMAN, A.B. (eds) Modern problems of palaeofloristics, palaeophytogeography and phytostratigraphy. Transection of the International Palaeobotanical Conference Moscow, May 17-18, 2005, GEOS, Moscow.

KVAČEK, Z. \& MANUM, S.B. 1993. Ferns of the Spitsbergen Palaeogene. Palaeontographica, Abteilung B 230, 169-181.

KVAČEK, Z. \& MANUM, S.B. 1997. A. G. Nathorst's (1850-1921) unpublished plates of Tertiary plants from Spitsbergen. $8 \mathrm{pp}$. Swedish Museum of Natural History, Department of Palaeobotany, Stockholm.

KVAČEK, Z., MAnum, S.B. \& Boulter, M.C. 1994. Angiosperms from the Palaeogene of Spitsbergen, including an unfinished work by A.G. Nathorst. Palaeontographica, Abteilung B 232, $103-128$

KVAČEK, Z. \& WALTHER, H. 1989. Revision der mitteleuropäischen tertiären Fagaceen nach blattepidermalen Charakteristiken. III. Teil. - Dryophyllum Debey ex Saporta und Eotrigonobalanus Walther \& Kvaček gen. nov. Feddes Repertorium 100, 575-601.

LAurent, L. 1899. Flore de calcaires de Célas. Annales du Musée d'Histoire Naturelle de Marseille 1, 1-148.

LAURENT, L. 1912. Flore fossile des schistes de Menat (Puy-deDome). Annales du Musée d'histoire naturelle de Marseille 14, $1-246$.

MAI, D.H.1968. Zwei ausgestorbene Gattungen im Tertär Europas und ihre florengeschichtliche Bedeutung. Palaeontographica, Abteilung B 123, 184-199.

MAI, D.H. 1976. Fossile Früchte und Samen aus dem Mitteleozän des Geiseltales. Abhandlungen des Zentralen Geologischen Instituts 26, 93-149.

MAI, D.H. 1995. Tertiäre Vegetationsgeschichte Europas. 681 pp. G. Fischer, Jena, Stuttgart \& New York.

MAI, D.H. \& SCHNEIDER, W. 1988. Über eine altertümliche Konifere und deren Bedeutung für Braunkohlen- und Bernsteinbildung. Feddes Repertorium 99, 101-112.

MAI, D.H. \& WALTHER, H. 1978. Die Floren der Haselbacher Serie im Weißelster-Becken (Bezirk Leipzig, DDR). Abhandlungen des Staatlichen Museums für Mineralogie und Geologie zu Dresden 28, 1-200.

MAI, D.H. \& WALTHER, H. 1983. Die fossilen Floren des Weißelster-Beckens und seiener Randgebiete. Hallesches Jahrbuch der Geowissenschaften 8, 59-74.

MAI, D.H. \& WALTHER, H. 1985. Die obereozäne Floren des Weißelster-Beckens und seiener Randgebiete. Abhandlungen des Staatlichen Museums für Mineralogie und Geologie zu Dresden $33,1-59$.

MAI, D.H. \& WALTHER, H. 2000. Die Fundstellen eozäner Floren des Weißelster-Beckens und seienr Randgebiete. Altenburger Naturwissenschaftlich Forschungen 13, 1-220.

MANCHESTER, S.R. 1994. Fruits and seeds of the Middle Eocene Nut Beds flora, Clarno Formation, Oregon. Palaeontographica Americana 58, 1-205.

MANCHESTER, S.R. 1999. Biogeographical relationships of North American Tertiary floras. Annals of the Missouri Botanical Garden 86, 472-522. DOI 10.2307/2666183

MANCHESTER, S.R., COLlinson, M.E. \& Goth, K. 1994. Fruits of the Juglandaceae from the Eocene of Messel, Germany, and implication for Early Tertiary phytogeographic exchange between Europe and western North America. International Journal of Plant Sciences 155, 388-394. DOI 10.1086/297176

MANCHESTER, S.R. \& HABLY, L. 1997. Revision of "Abelia" fruits from the Paleogene of Hungary, Czech Republic and England. Review of Palaeobotany and Palynology 96, 231-240.

DOI 10.1016/S0034-6667(96)00055-3

MANCHESTER, S.R. \& KVAČEK, Z. 2009. Fruits of Sloanea (Elaeocarpaceae) in the Paleogene of North America and Greenland. International Journal of Plant Sciences 170(7), 941-950. DOI $10.1086 / 600148$

MANCHESTER, S.R., Wilde, V. \& COLlinson, M.E. 2007a. Fossil cashew nuts from the Eocene of Europe: biogeographic links between Africa and South America. International Journal of Plant Sciences 168(8), 1199-1206.

DOI 10.1086/520728

MANCHESTER, S.R., XIANG QIU-YUN (JENNY), XIANG QIAO-PING 2007b. Curtisia (Cornales) from the Eocene of Europe and its phytogeographical significance. Botanical Journal of the Linnean Society 155, 127-134.

DOI 10.1111/j.1095-8339.2007.00680.x

MAZER, S.J. \& TIFFNEY, B.H. 1982. Fruits of Wetherellia and Palaeowetherellia (Euphorbiaceae) from Eocene sediments in Virginia and Maryland. Brittonia 34, 300-333. DOI $10.2307 / 2806703$

MiHAJLOVIĆ, S.D. 1985. Palaeogene fossil flora of Serbia. Annales Géologiques de la Péninsule Balkanique 49, 1-434.

MiHAJlović, S.D. 1990. Paleogene flora of Yugoslavia (a review), 141-146. In KNOBLOCH, E. \& KVAČEK, Z. (eds) Proceedings of the Symposium "Paleofloristic and paleoclimatic changes in the Cretaceous and Tertiary”, Prague 1989. Geological Survey, Prague.

MiHAJLOVIĆ, S.D. \& LJUBOTENSKI, T. 1994. Upper Eocene flora of Ovče Polje, Macedonia. Geologica Carpathica 45(4), 203-210.

PALAMAREV, E. 1973. Die eozäne Flora des Burgas-Beckens. Mitteilungen des botanischen Instituts Sofia 24, 75-124.

PalamareV, E. \& PetKovA, A. 1975. Novi danni za Paleogenskata flora na B'lgarija[New data on the Paleogene flora of Bulgaria], 203-236. In honour of Akad. Daki Jordanov. Bulgarian Academy of Sciences, Sofia.

Palamarev, E., Kitanov, G., Bozukov, V. \& Staneva, K. 1999. Fossil flora from Paleogene sediments in the northern area of the Mesta Graben in the Western Rhodopes. I. Systematics. Phytologia Balcanica 5(2/3), 3-25. 
PANTIĆ, K.N. \& MiHAJlOVIĆ, S. DJ. 1985. The problems of Eocene and Oligocene in Serbia and further researching trends. Bulletin geologique, Sarajevo 28(II), 41-55.

PANTIĆ, K.N. \& NiCOLIĆ, P. 1955. Prvi priloog poznavan'u fosilne flore iz senonskog rona istochie Srbie [The first annex to cognition of fossil flora from Sennonian tectonic trench of Eastern Serbia]. Annales Géologiques de la Péninsule Balkanique 23, 91-106.

Petrescu, J. \& DUSA, A. 1970. Asupra unui sou punct palaeofloristic din cretacicul al bazinului Rusca Montană. [On a paleofloristic locality from the Cretaceous in the basin of Rusca Montană]. Bulletinul Soccientății de științe geologice din R.S. Romănia 12, 165-172.

PETRESCU, J. \& DUSA, A. 1980. Flora din cretacicul superior de la Rusca Montană [Flora of the Upper Cretaceous from Rusca Montană]. Ocrotirea naturii și a mediului înconjurător, natura terra 24(2), 147-155.

Petrescu, J. \& Givulescu, R. 1987. Considerations on the Eocene vegetation in the North Western part of the Basin of Transylvania, 59-70. In PETRESCU, J. (ed.) The Eocene from the Transylvania Basin, Romania. University of Cluj-Napoca, Cluj-Napoca.

PETRESCU, J., MĂRGĂRIT, G. \& MĂRGĂRIT, M. 1976. Flora eocenă de la Gîrbou - Cluj [Eocene flora of Gîrbou - Cluj]. Dări de Seamă ale ședințelor Ministerul Geolofiei Insitutul de Geologie și Geofizică 3. Paleontologie 62, 195-228.

PigG, K.B. \& DEVore, M.L. 2005. Paleoactaea gen. nov. (Ranunculaceae) from the Paleogene of North Dakota and the London Clay. American Journal of Botany 92, 1650-1659. DOI 10.3732/ajb.92.10.1650

PITON, L.E. 1940. Paléontologie du gisement Éocène de Menat (Puy-de-Dôme). Mémoires de la Société d'Histoire Naturelle d'Auvergne 1, 1-305.

Poulter, J., Francis, J., Wilson, M., CANDEla, Y. \& ANDERSON, L. 2009. Deciphering floral diversity and palaeoclimate signals from the Mid-Palaeocene floras in the Isle of Skye, Scotland. Abstract, $19^{\text {th }}$ Plant Taphnonomy Workshop, Utrecht.

RAsmussen, J. \& KoCH, B.E. 1963. Fossil Metasequoia from Mikines, Faroe Islands. Annals of the Society Scientific Faeroensis 12, 83-96.

REID, E.M. \& CHANDLER, M.E.J. 1926. Catalogue of Cainozoic plants in the Department of Geology. I. The Bembridge flora. 206 pp. British Museum (Natural History), London.

REID, E.M. \& CHANDLER, M.E.J. 1933. The London Clay Flora. 561 pp. British Museum (Natural History), London.

RÜFFLE, L. 1976. Myricaceae, Leguminosae, Icacinaceae, Sterculiaceae, Nymphaeaceae, Monocotyledonae, Coniferae. Eozäne Floren des Geiseltales. Abhandlungen des Zentralen Geologischen Instituts 26, 337-348.

RÜFFLE, L. \& JÄHNICHEN, H. 1976. Die Myrtaceen im Geiseltal und an einigenanderen Fundstellen des Eozäns. Eozäne Floren des Geiseltales. Abhandlungen des Zentralen Geologischen Instituts 26, 307-336.

RÜFfle, L., MÜller-Stoll, W.R. \& LitKe, R. 1976. Weitere Ranales, Fagaceae, Loranthaceae, Apocynaceae Eozäne Floren des Geiseltales. Abhandlungen des Zentralen Geologischen Instituts 26, 199-282.

SAPORTA, G. 1879. Le monde des plantes avant l'apparition de l'homme. 416 pp. G. Masson, Paris.

SAPORTA, G. \& MARION, A.F. 1873. Essai sur l'état de la végétation à l'époque des Marnes Heersiennes de Gelinden. Mémoires couronnes et Mémoires des savants étrangés 37, 1-94.
SAPORTA, G. \& MARION, A.F. 1878. Révision de la flore Heersiennes de Gelinden. Mémoires couronnes et Mémoires des savants étrangés $41,1-112$.

SCHLOEMER-JÄGER, A. 1958. Alttertiäre Pflanzen aus Flözen der Brögger-Halbinsel Spitsbergens. Palaeontographica, Abteilung B 104, 39-104.

SCHWEITZER, H.-J. 1974. Die „Tertiäre“ Koniferen Spitzbergens. Palaeontographica, Abteilung B 149, 1-89.

SEWARD, A.C. 1931. Plant life through the ages. 601 pp. University Press, Cambridge.

Smith, S.Y., Collinson, M.E. \& Rudall, P.J. 2008. Fossil Cyclanthus (Cyclanthaceae, Pandanales) from the Eocene of Germany and England. American Journal of Botany 95, 688-699. DOI 10.3732/ajb.2007390

TuZSON, J. 1913. Beiträge zur fossilen Flora Ungarns. Beiblatt Növínyitani Közlemények 1908(1), 1-4.

TUZSON, J. 1914. Beiträge zur fossilen Flora Ungarns. Mitteilungen aus dem Jahrbuch der Königlichen Ungarischen Geologischen Reichsanstalt 21(8), 231-261.

Uhl, D., TrAiser, C., Grisser, U. \& DENK, T. 2007. Fossil leaves as palaeoclimate proxies in the Palaeogene of Spitsbergen. Acta Palaeobotanica 47(1), 89-107.

UNGER, F. 1850. Die fossile Flora von Sotzka. Denkschriften der Kaiserlichen Akademie der Wissenschaften, Mathematischnaturwissenschaftliche Classe 2, 131-167.

WAtelet, A. 1866. Description des plantes fossiles de bassin de Paris. 264 pp. Baillière, Paris.

WILDE, V. 1989. Untersuchungen zur Systematrik der Blattreste aus dem Mitteleozän der Grube Messel bei Darmstadt (Hessen, Bundesrepublik Deutschland). Courier Forschungsinstitut Senckenberg 115, 1-215.

WILDE, V. 2004. Aktuelle Ubersicht zur Flora aus dem mitteleozänen "Ölschiefer" der Grube Messel bei Darmstadt (Hessen, Deutschland). Courier Forschungsinstitut Senckenberg 252, 109-114.

WILDE, V. 2005. The Green Eocene. The diverse flora of a paratropical climate. Vernissage UNESCO World Heritage Series 21(151), 14-19.

WILDE, V. \& FRANKENHÄUSER, H. 1998. The Middle Eocene plant taphocoenosis from Eckfeld (Eifel, Germany). Review of Palaeobotany and Palynology 101, 7-28. DOI 10.1016/S0034-6667(97)00067-5

WILDE, V. \& FRANKENHÄUSER, H. 1999. Comptonia like leaves from the German Middle Eocene. Acta Palaeobotanica Supplementum 2, 447-463.

Wilde, V. \& MANCHESTER, S. R. 2003. Cedrelospermum-fruits (Ulmaceae) and related leaves from the Middle Eocene of Messel (Hesse, Germany). Courier Forschungsinstitut Senckenberg 241, $147-153$.

Wilde, V., KVAČEK, Z. \& BogneR, J. 2005. Fossil leaves of the Araceae from the Eocene of Europe. International Journal of Plant Sciences 166, 157-183. DOI 10.1086/425673

ZHILIN, S.G. 1986. Smena ekologicheskikh tipov flory na Ukraine i yuge Srednerusskoy vozvyshennosti v kontse paleogena-nachala neogena [Exchange of ecological types of flora in Ukraina and the south Midrussian Upland in the end of the Paleogene - beginning of the Neogene], 72-84. In TAKHTAJAN, A.L. (ed.) Problemy paleobotaniky. Nauka, Leningrad.

ZHILIN, S.G. 1989. History of the development of the temperate forest flora in Kazakhstan U.S.S.R. from the Oligocene to the Early Miocene. Botanical Review 55(4), 205-330. DOI 10.1007/BF02858522 